\title{
972
} 3rd INTERNATIONAL CONFERENCE ON BUSINESS AND ECONOMIC RESEARCH ( 3rd ICBER 2012 ) PROCEEDING

12 - 13 MARCH 2012. GOLDEN FLOWER HOTEL, BANDUNG, INDONESIA

ISBN: 978-967-5705-05-2. WEBSITE: www.internationalconference.com.my

\section{THE UNDERLYING DIMENSIONS OF RELATIONSHIP MARKETING IN THE MALAYSIAN MOBILE SERVICE SECTOR}

\author{
Jamil Bojei ${ }^{a}$ and Alias Radam ${ }^{b}$ \\ Faculty of Economics and Management \\ Universiti Putra Malaysia \\ ajamil@putra.upm.edu.my \\ ${ }^{b}$ alias@econ.upm.edu.my \\ Mimi Liana Abu \\ Graduate School of Management \\ Universiti Putra Malaysia \\ a.b.milia@gmail.com
}

\begin{abstract}
After so many years, the Malaysian mobile service market is getting saturated whereby the service operators had difficulties to differentiate themselves since they had offered almost the same services. As the service options are wide, therefore customers become less committed to a particular provider and might easily shift from one operator to another. This situation forces the service providers to create a strategy that focuses more on gaining and retaining long term relationship with their customers. Therefore, the objective of this study is to determine the underlying dimensions of relationship marketing in the Malaysian mobile service sector. A sample of 300 customers is drawn using Mall Intercept Scientific Procedures around Klang Valley and the Structural Equation Model (SEM) is utilized in testing the proposed model. The results show that the relationship between the exogenous latent factors and the overall endogenous factor are significant ranging from 0.77 to 0.94 . That is, relatively high proportion of the variance in relationship marketing are well-explained by each of the factors.
\end{abstract}

Field of Research: Relationship Marketing, Underlying Dimensions, Mobile Service, Structural Equation Model.

\section{Introduction}

The mobile service sector is one of the fastest growing sectors within the telecommunication industry in Malaysia. With the significant growth and huge attention given, this sector however has reached to maturity stage where service providers have difficulties to differentiate themselves and thereby reducing their profit margins. This is because every service provider is offering almost the same services, making customers use several services offered by several service providers. As the service options are wide and switching cost is low, therefore customers become less committed to a particular provider and 
might easily shift from one operator to another. This situation forces the service providers to be more individual-oriented in order to gain and retain long term profitable relationship with their customers.

Relationship marketing has been widely considered as a company's activity that helps in developing and retaining long term relationship through increased loyalty, satisfaction, trust and commitment (Kumar and Reinartz, 2002). This is important since the cost of serving one loyal customer is five to six times less than the cost of attracting and serving one new customer (Ndubisi, Malhotra and Wah, 2009). The reason is that the loyal customers always come back to the service provider when they need services, yet they will not easily switch to the competitors and typically are not price sensitive. In fact, they might be able to be a part of the firm when they indirectly promote the service to their friends and family by spreading positive word-of-mouth. The above reasons reflect the use of relationship marketing as crucial, especially for the firms in the matured stage as happened to the Malaysian mobile service providers.

In order to encourage loyalty, some mobile service operators may prefer to use variety of special offers such as price discount, hoping that customers will stay with them if they have this special offer. Unfortunately, this kind of monetary approach is less practical for long term purpose and insufficient enough in retaining customers. One of the reasons is that most mobile users in Malaysia are prepaid customers who shop around for bargain. That is, they look for the operator that offers low charges and most probably will switch to other operators that offered lower charges. Another reason is that the probability of such monetary approach to be imitated by the competitors is high. Therefore, it is imperative for the service operators to employ a non-monetary approach such as relationship marketing. Unlike other monetary approaches, relationship marketing is not merely able to deliver enlarged value to the customer over and above the firm's product and service offering, yet able to build a strong customer relationship which offers a significant competitive advantage due to the difficulty of this approach to be imitated by the competitors.

While there has been huge attention paid to relationship marketing by practitioners and academics, however to the best of my knowledge, fewer systematic attempt has existed to develop a valid measure for it. It is admitted by Sin et al. (2005), that there are plenty of research that have underlined the dimensions of relationship marketing, however few of them have developed a valid measurement scale and testing the concept empirically. Consequently, Sin and colleagues (2005) studied the scale development of Relationship marketing orientation (RMO) but the study focused heavily on business perspective, which is firm performance. Therefore, there is a need for the present research to examine the underlying dimensions of relationship marketing, specifically that concern consumer perspectives.

In addition, most of the existing studies have employed a single dimension in measuring relationship marketing, while few of them used at most three to four dimensions. This is the reason why Callaghan et al. (1995) criticized the overly simplistic past studies on relationship marketing, as they rather used a single component perspective. For example, Soureli, Lewis and Karantinou (2008) have examined trust as a sole factor of relationship marketing that affect customers' intention of cross-buying in retail financial services, while other variables such as commitment and bonding are omitted. In other studies, Ndubisi et al. (2009) focused on competence, conflict handling, and communication in examining the effect of relationship marketing towards satisfaction and loyalty. The exclusion of the trust and commitment is based on a claim that they are extensively discussed by previous studies. Therefore, the present study intends to empirically and intensively examine the key underlying dimensions of relationship marketing, particularly for the setting of customer-service based study. 


\section{Literature Review}

\subsection{Relationship Marketing in Service Industry}

The concept of relationship marketing emerged as an opponent to traditional marketing theories since early 1990s, when the paradigm shifted from transactional to relational marketing. At that time, marketers started to realize that a long lasting relationship is more profitable than a onetime transaction. This is in line with the fact that the cost of serving one loyal customer is five to six times less than the cost of attracting and serving one new customer (Ndubisi et al., 2009, Ndubisi, 2003, Reichheld et al., 2000). Since that, relationship marketing had received an increasing amount of attention in marketing research (Gronroos, 1994; 1999), especially in the service industry.

Apart from that, the reality of many services being consumed in an ongoing or periodic basis such as insurance and telecommunication (Lovelock, 1983), coupled with the reality of customers forming relationship with people rather than goods paves the way for relationship marketing. In fact, repeat interaction between customers and service providers offered wide opportunity for relationship marketing to exist (Wong and Sohal, 2002). Even when membership is not required, customers may ask for on-going relationships with the service providers to reduce their perceived risk in evaluating services. Moreover, intangibility of services causes the evaluation of the service values to be more subjective (Berry, 1983; Zeithaml et al., 1993), thereby customer appraisal criteria are unobviously expressed. As a result, customers tend to evaluate based on the relationship that they formed with the individuals and organizations rather than goods (Bendapudi and Berry, 1997; Wong and Sohal, 2002).

Nonetheless, it is vital to know that relationship marketing is not applicable to every service situations, as emphasized by Barnes (2002). The application of relationship marketing is most relevant to a service basis company when each of the following conditions are fulfilled: 1 ) the customer must has an ongoing or periodic desire for the service (e.g., telephone versus funeral home service); (2) the service customer must control the selection of the supplier (e.g., selecting a dry cleaner versus entering the first taxi in the airport waiting line); and (3) there must be alternate suppliers (e.g., patronizing various restaurants versus buying electricity from the one electric utility serving a community). Similarly, Berry (1983) also suggested that the three conditions above should exist in an attempt for relationship marketing to be useful.

\subsection{The Selection of Study Underpinnings}

Prior marketing literature documented different key underpinnings of relationship marketing across study settings. As an example, Chattananon and Trimetsoontorn (2009) in their study on relationship marketing in a business context used four common components including bonding, empathy, reciprocity and trust. It is different with the customer-based study of Ndubisi (2007) who employed trust, commitment, communication and conflict handling as key constructs of relationship marketing. As there is little agreement among researchers as to which dimensions best capture the concept of relationship marketing, the selection of this study underpinnings was made as follows.

Among all the factors, trust is most accepted by the researchers of relationship marketing, both in business and customer context. This is why Lingreen (2001) included trust in his comprehensive model 
of relationship marketing, together with commitment, cooperation, communication, shared values, conflict, power, and non-opportunistic behavior. In fact, Berry (1995) claimed that trust is a single most powerful relationship-based marketing tool. That is, either in business or customer context, trust is one of the factors that appeared mostly in the marketing relationship literature.

Other than trust, Alrubaiee and Al-Nazer (2010) conceived that two more factors that are consistently identified as important are relationship commitment (Anderson and Weitz 1992; Day, 1995; Moorman et al., 1992), and communication (Mohr and Nevin, 1990; Mohr et al., 1996). In fact, literature found that these three factors (including trust) are consistently used in the most cases of customer study. For example, Ndubisi and Chan (2005), Ndubisi (2007), Ndubisi et al. (2009) and Kamaruzaman et al. (2009) consistently included trust, commitment and communication as the underpinnings of relationship marketing, in which all the studies examined the relationship marketing from customer point of view.

In addition to the three factors, this study intends to take into account conflict handling, empathy, and bonding as the underlying dimension of relationship marketing. These factors are regularly appeared in the business based study such as business performance (e.g., Sin et al., 2002; 2005; Callaghan et al., 1995; Kucukkancabas et al., 2007; and Chattanon and Trimetsoontorn, 2009) however they increasingly received great attention by relationship marketing studies. The specific reasons for inclusion of the three other dimensions are as follows. First, conflict handling is well utilized by researchers in understanding relationship marketing, particularly in service marketing (e.g. Lingreen, 2001; Ndubisi and Chan, 2005; Ndubisi, 2007; Ndubisi et al., 2009) thus the inclusion of this dimension is considered relevant, as the present study focuses on service context as well. Second, it was suggested by Ndubisi and Chan (2005) for future research to include more comprehensive list of relationship marketing factors such as empathy, so that a richer outcome may emerge. Yet, as Chattanon and Trimetsoontorn (2009) found that bonding and empathy are significant on firm's performance, thus it was suggested for future research to expand investigation among stakeholders such as customers, as well as across different industries. Last but not least, although the uses of conflict handling, empathy, and bonding are found mostly in business cases, however they are thought as appropriate to be tested on consumers in the mobile service sector. Further review of each dimension will be discussed next.

\section{Trust}

Recently, Chattananon and Trimetsoontorn (2009) defined trust as a belief or conviction about the other party's intention within the relationship, while other scholars have defined trust as shared values (Morgan and Hunt, 1994), mutual goals (Wilson, 1995), opportunistic behavior (Dwyer et al., 1987; Morgan and Hunt, 1994), making and keeping promises (Bitner, 1990; Bitner et al., 1994), and uncertainty (Crosby et al., 1990). Trust is the most common variable that has been used in operationalizing relationship marketing. In fact, the inclusion of trust as a central variable in a relational marketing has been widely examined in the marketing literature (Andaleeb, 1992; Crosby et al., 1990; Gronroos, 1990, Moorman et al., 1992; Sullivan and Peterson, 1982). It is considered to be important due to the fact that customer-seller relationship will not develop if they do not trust each other. In addition, trust is truly important especially for service industry due to the concept of intangibility that portrays the service itself. Service which is unable to be seen, felt or even touched is incapable to refute the relevance of trust in reducing perceived risk by customers in a transaction. For that reason, Berry and Parasuraman (1991) said that customer-company relationships in service marketing require trust. As trust declines, people are increasingly unwilling to take risks and demand greater protection against the probability of betrayal. 


\section{Commitment}

Other than trust, commitment is another important underpinning of relationship marketing and its definition is used differently across study settings. In psychology, scholars described commitment as a decision or recognition that fix or bind an individual to a behavioral disposition (Kiesler, 1971), while sociologist used the concept of commitment as a descriptive concept to mark out forms of action characteristics of particular kinds of people or groups (Wong and Sohal, 2002). Although various field of study defined commitment in slightly different ways, however marketing defined it as an enduring desire to maintain a value relationship (Moorman et al., 1992). Commitment would increase between customer and firm if they believe that they will receive more values and benefits from a relationship. Therefore, to achieve customer commitment, a company's strategy must be centered, long term and based on mutual relationship benefits (Adamson, Chan and Handford, 2003).

\section{Communication}

Communication refers to both formal and informal sharing of meaningful and timely information between firms (Anderson and Narus, 1990). Moreover, the effective communication must be based on a two-way communication which the interactive dialogue between the firm and its customers should takes place during the pre-selling, selling, consuming, and post-consuming stages. For that reason Andersen (2001) conceived that communication plays a critical role in relationship marketing as it provides an understanding of the exchange partner's intentions and capabilities so that the strong basis for relationship development would be formed. In fact, it was agreed as the essence of coordinating behavior in any organizational setting and relationship marketing by previous literature (Cummings, 1984; Hutt and Speh, 1995).

\section{Conflict Handling}

According to Dwyer et al. (1987), conflict handling is an ability of the firm to minimize the consequences of apparent and potential conflicts that may happen in buyer-seller relationship. That is, conflict handling does not merely take place when something goes wrong in a relational exchange, however able in minimizing the gaps that may influence customer complaint. Many researchers acknowledged that conflict is unavoidable and naturally occurs in business relationships due to existing interdependencies and the complex nature of such relationships (Mohr and Spekman, 1994; Jehn, 1995; Duarte and Davies, 2003), especially in service sector. However, not all conflicts have negative effects on relationship (Anderson and Weitz, 1992), and not necessarily will be destructive to the development of relationship (Morgan and Hunt, 1994). Nevertheless, it is undeniable that the manner in which conflict is solved has an implication for partnership success (Mohr and Spekman, 1994). Moreover, Weitz and Jap (1995) argued that conflicts can often act as source of novelty for the relationship and if handled successfully can strengthen the interpersonal relationship between customers and the firm.

\section{Bonding}

Bonding has been considered as a component of a business relationship involving buyer and seller acting in a cohesive manner toward a desired goal (Callaghan et al., 1995). According to Wilson (1995), bonding can be classified into two categories: social bond and structural bond. However, most studies have identified three types of relational bonding: financial, social and structural (Arantola, 2002; Liang and Wang, 2005; Lin, Weng, and Hsieh, 2003; Peltier and Westfall, 2000; Williams et al., 1998). As suggested by literature, businesses can build customer relationships by initiating one or several types of these bonds. Yet, Arantola (2002) recommended that a relational bond is a key aspect of relationship management. This is because bonding as it applies to relationship marketing refers to the feelings of 
affection and a sense of belonging to the relationship which it indirectly causes a sense of belonging to the organization (Sin et al., 2002). Thus, a long-term relationship requires bonding to exist.

\section{Empathy}

Empathy enables two parties to understand each other's desires and goals in a truly cognitive sense, and thereby fostering a positive relationship between them (Yau et al., 2000). As far as relationship marketing is concerned, attention is shifted toward consumers as individuals where increased attention is paid to individual customer preferences rather than mass marketing. Due to that, Kucukkancabas et al. (2007) agreed that empathy is the dimension of a business relationship that enables the two parties to see the situation from the other person's perspective. The importance of empathy not merely discussed in business relationship, however in the buyer-seller relationship as well. Berger (2009) in his recent article declared that empathy is a missing element in relationship marketing, as failure to be empathic will cause failure of understanding customer's feelings and needs. In fact, Barlow and Maul (2000) asserted that firms in service industry should pay individualized attention to the people they serve and develop the ability to empathize.

\section{Methodology}

The targeted population of this study is mobile phone subscribers in Klang Valley. Klang Valley was choosen because it has a high population of 6 million people (Department of Statistics Malaysia, 2008) with large number of migrants from other states within Malaysia. In all, 300 usable questionnaires are gathered using scientific procedure of mall intercept. By applying this procedure, every customer who entered the entrance or appears at the survey point at every five minutes was intercepted and asked if they would be willing to participate in a research study.

Table 1 indicates the measures of the study variables used in the study. The questionnaire items are adapted from different sources to suit mobile service study including Roberts et al., 2003; Alrubaiee and Al-Nazer, 2010; Ndubisi and Chan, 2005; Ndubsi et al., 2009; and Sin et al., 2002. All items are measured using a six-point Likert scale ranging from 1 "strongly disagree" to 6 "strongly agree".

Table 1: Measures of the Study Variables

\begin{tabular}{lcl}
\hline Study Variables & No of items & Sources \\
\hline Trust & 9 items & Roberts et al., 2003; Alrubaiee and Al-Nazer, 2010 \\
Commitment & 6 items & Alrubaiee and Al-Nazer, 2010; Ndubisi and Chan, 2005 \\
Communication & 7 items & Alrubaiee and Al-Nazer, 2010; Ndubsi et al., 2009 \\
Conflict Handling & 7 items & Ndubisi and Chan, 2005 \\
Empathy & 4 items & Alrubaiee and Al-Nazer, 2010 \\
Bonding & 9 items & Sin et al., 2002 \\
\hline
\end{tabular}

As this study aims to know if the six constructs significantly underlie the relationship marketing, therefore the hierarchical CFA (second order) is performed and the analysis is conducted with relationship marketing being measured as a second order. The reason for using the second order model is that, it is most appropriate in research context in which measurement instruments assess several related constructs, and each of them is measured by multiple items (Chen, Sousa and West, 2005). Kline 
(2011) pointed that, to identify a hierarchical CFA model, there must be at least three first-order factors and each first-order factor should have at least two indicators. Otherwise, the direct effects of the second-order factor on the first-order factors or the disturbance variances may be under identified. As shown, the model in Figure 1 satisfies both these requirements.

The second order model hypothesized that these constructs (trust, commitment, communication, conflict handling, bonding and empathy) although seemingly distinct, but they are related and can be counted for by one or more common underlying higher order constructs (relationship marketing). Unlike first-order model with correlated factors, second order factor model has ability to provide more parsimonious and interpretable model when researcher hypothesized that higher order factor underlie their data (Chen et al., 2005).

\section{Results}

\subsection{Respondents Profile}

From the results, not much different in terms of the number of participants between male and female ( $51 \%$ and $49 \%$, respectively). Half of the respondents are Malay $(50 \%)$, while the rest are represented by other ethnic groups, which are Chinese, Indian and others (35\%, $12 \%$ and $3 \%$, respectively). About half of the respondents are single (51.3\%), followed by married, widowed, separated, and divorced $(44.7 \%, 1.7 \%, 1.3 \%$, and $1.0 \%$, respectively). Besides that, majority of the respondents have attained at least SPM and STPM/Matriculation/Diploma (75\%), 20\% are bachelor degree holders, while $4 \%$ have Master degree/PhD. In terms of age, majority of the respondents are 40 years old and below $(90.3 \%)$, while those who are between $41-50$ years old are $8 \%$. Only $2 \%$ of the respondents are more than 51 years old. For monthly income, about $25 \%$ of the respondents have a monthly income of RM1, 000 or less, whereas majority of the respondents (73\%) have income not more than RM5, 000. In addition, the result shows that the numbers of prepaid customers are higher (61\%) than postpaid customers (33\%), while $6 \%$ of the respondents use both prepaid and postpaid service.

\subsection{Second-order Factor Model of Relationship Marketing}

In order to test the measurement model of relationship marketing, this study creates one second-order factor (RM) and six correlated first-order factors, labeled as (TRS) Trust, (CMT) Commitment, (COM) Communication, (CH) Conflict Handling, (BND) Bonding, and (EMP) Empathy. To facilitate interpretation of Figure 1, the six first-order factors are bounded by eclipses and the item descriptions within each first-order factor are bounded by rectangles. The result of initial model indicates that the goodness-of-fit indices are not within the recommended level. In order to develop a better fit and more parsimonious model, a proper assessment was performed including the examination of factor loadings and modification indices.

The assessment resulted in removing 19 items that obtain low factor loadings and unacceptable high modification indices. As shown in Table 2, five items (B1, B2, B3, B4 and B5) were removed from trust, three items from commitment (B10, B11, B12), three items from communication (B18, B17, B22), three items from conflict handling (B23, B27, and 29), four items from bonding (B30, B31, B32 and B34) and one item from empathy (B39). Although the number of deleted items is relatively high, their removals 


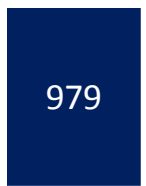

3rd INTERNATIONAL CONFERENCE ON BUSINESS AND ECONOMIC RESEARCH ( 3rd ICBER 2012 ) PROCEEDING

12 - 13 MARCH 2012. GOLDEN FLOWER HOTEL, BANDUNG, INDONESIA

ISBN: 978-967-5705-05-2. WEBSITE: www.internationalconference.com.my

do not significantly change the content of the construct as it is conceptualized. This is because the remaining items for each construct have the highest initial loadings, and thus the meanings of the factors are preserved by these items.

Table 2: The Summary of Model Assessment

\begin{tabular}{lll}
\hline Dimensions & Items deleted & Goodness of Fit Indices (Modified Model) \\
\hline Trust & $\mathrm{B} 1, \mathrm{~B} 2, \mathrm{~B} 3, \mathrm{~B} 4$ and B5 & $x^{2}=390.68(\mathrm{df}=224, \mathrm{P}=.0001)$ \\
Commitment & $\mathrm{B} 10, \mathrm{~B} 11, \mathrm{~B} 12$ & $\mathrm{GFI}$ is .902 \\
Communication & $\mathrm{B} 18, \mathrm{~B} 17, \mathrm{~B} 22$ & $\mathrm{AGFI}=.879$ \\
Conflict Handling & $\mathrm{B} 23, \mathrm{~B} 27$, and 29 & $\mathrm{CFI}=.966$ \\
Bonding & $\mathrm{B} 30, \mathrm{~B} 31, \mathrm{~B} 32$ and B34 & $\mathrm{RSMEA}=.050$ \\
Empathy & $\mathrm{B} 39$ & $x^{2} / \mathrm{df}=1.74$. \\
\hline
\end{tabular}

After iteratively removing these items, the hierarchical CFA was performed again with 23 remaining items. Accordingly, the modified model as presented in Figure 1 shows that all items for each factor are highly loaded, ranging from 0.71 to 0.92 . It indicates that there is a strong association between each of the latent factors and their respective items. The factor loadings are meaningful and statistically significant. In the second order model, the relationship between the exogenous latent factors (TRS, $\mathrm{CMT}, \mathrm{COM}, \mathrm{CH}, \mathrm{BND}$ and EMP) and the overall endogenous factor (RM) are also significant, ranging from 0.77 to 0.94 . That is, relatively high proportion of the variance in relationship marketing are wellexplained by each of first-order factor.

Figure 1: Second-order Factor Model of Relationship Marketing 


\section{0}

\section{3rd INTERNATIONAL CONFERENCE ON BUSINESS AND ECONOMIC RESEARCH ( 3rd ICBER 2012 ) PROCEEDING}

12 - 13 MARCH 2012. GOLDEN FLOWER HOTEL, BANDUNG, INDONESIA

ISBN: 978-967-5705-05-2. WEBSITE: www.internationalconference.com.my

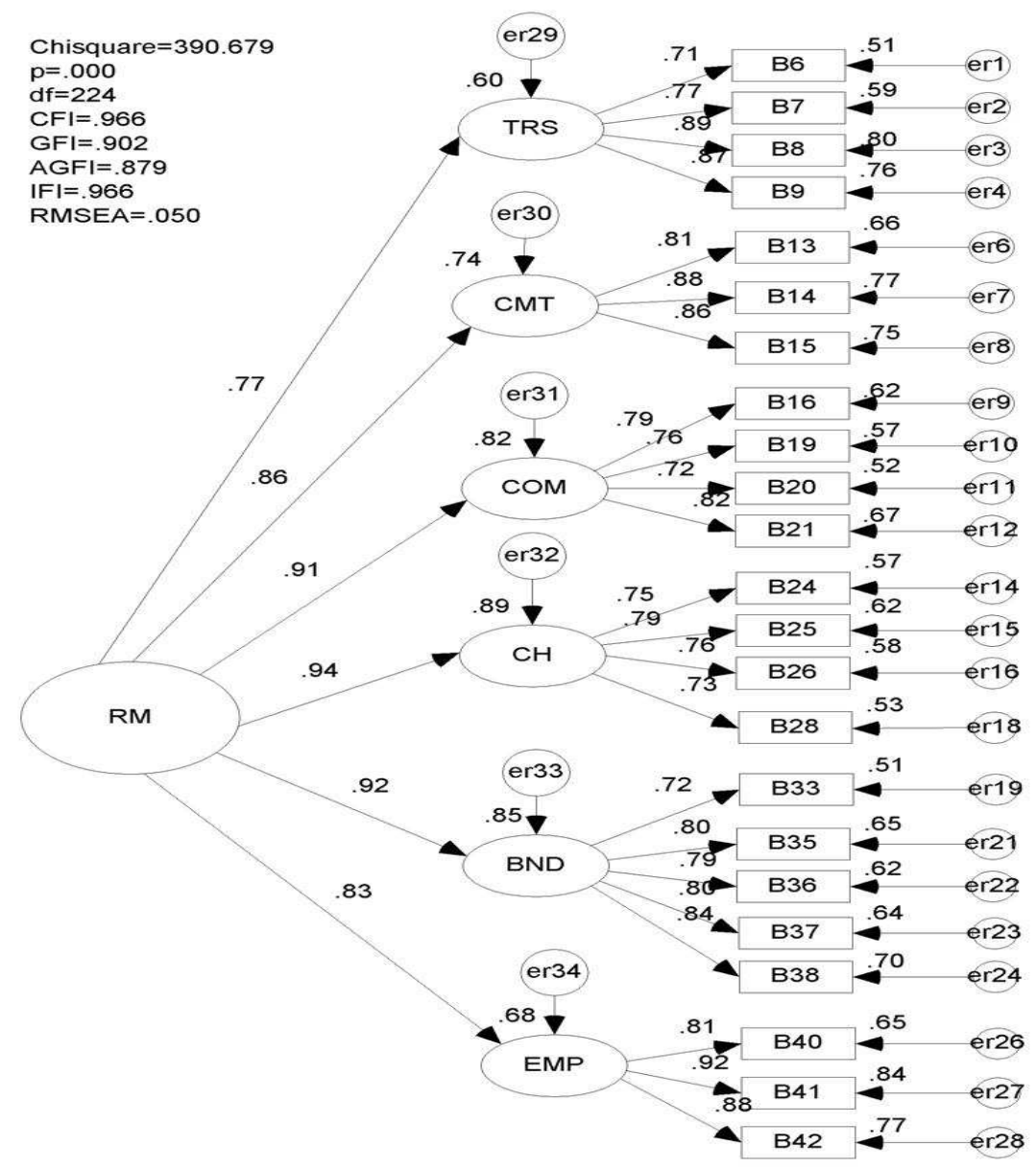

Additionally, the modified measurement model is found to better fit the data adequately, although the chi-square is still significant. As discussed, the measurement provides an acceptable fit even though the chi-square value is statistically significant (Anderson and Gerbing, 1988), especially with a large sample (Bagozzi and Yi, 1988). The chi-square is $x^{2}=390.68(\mathrm{df}=224, \mathrm{P}=.0001, N=300)$. The GFI is .902, AGFI = $.879, \mathrm{CFI}=.966, \mathrm{RSMEA}=.050$, and $x^{2} / \mathrm{df}=1.74$. While AGFI is slightly below the threshold of .9 , other indices are within the recommended threshold levels, thus this model is considered to be an acceptable one. In fact, Hair et al. (2006), and Holmes- Smith et al. (2006) have suggested the use of at least three fit indices by including one in each of the categories of model fit (absolute fit measures, incremental fit measures, and parsimonious fit measures) in an attempt to reflect diverse criteria and provide the best overall picture of the model fit. Given that the model fits the data adequately and all the observed variables (items) loaded highly and significantly on the respective latent factor, therefore no further adjustments are required.

\subsection{Reliability and Validity}

In order to assess the reliability of the measurement, this study used cronbach's alpha, Construct Reliability (CR), and Average Variance Extracted (AVE), and for assessing validity, the construct, convergent and discriminant validity are employed. 
As presented in Table 3, the Cronbach's Alpha for the construct's dimensions are as follows: Trust (.878), Commitment (.880), Communication (.865), Conflict Handling (.841), Bonding (.891), Empathy (.896), Customer Satisfaction (.909), Customer Loyalty (.918), and Cross Buying (.866). The results of Cronbach's coefficient alpha for all constructs exceed the suggested level of .70 (Nunnally, 1978), providing evidence for internal consistency. In addition, the CFA result shows that the measurement of CR ranging from 0.846 to 0.919 , whereas AVE ranging from 0.563 to 0.755 . As the CR are greater than .60 and AVE are greater than .50, as suggested by Bagozzi and $\mathrm{Yi}$ (1988), therefore the measurement indicators used in this study are within the acceptable levels and providing evidence for construct reliability (see Table 3).

After reliability of the measures is confirmed, next, construct, convergent and discriminant validity are assessed using CFA. Construct validity exists when the measure correctly measures its targeted variable. In fact, construct validity is required for theory testing (Bagozzi, 1980). In this study, the model provides an adequate fit of the data and confirmed construct validity since the goodness-of-fit index is above 0.90 (Hsieh and Hiang, 2004; Jöreskog and Sörbom, 2004). In addition, construct validity is confirmed by evaluating the percent of the total variance explained per dimension obtained from CFA (Jöreskog and Sörbom, 2004). The percent of total variance explained values shown in Figure 1 are much higher than 0.5 , indicating acceptable construct validity (Hair et al., 2006).

In the case of convergent validity, evidence has been found when all factor loadings for items measuring the same construct are statistically significant (Lin and Ding, 2005; Holmes-Smith et al., 2006) and have high factor loadings (Hair, et al, 2006). As presented in Table 3, all factors have high loadings (greater than .50) and are statistically significant $(P<0.001)$, thus meeting the requirement of convergent validity. In addition, the results of AVE presented in Table 3 are all above 0.5 , providing an additional support for convergent validity (Fornell and Larcker, 1981).

Table 3: Measurement Model Evaluation

\begin{tabular}{|c|c|c|c|c|c|}
\hline Construct & Items & $\begin{array}{l}\text { Standardized } \\
\text { Loading }\end{array}$ & $\begin{array}{l}\text { Cronbach's } \\
\text { alpha }(\alpha)\end{array}$ & CR & AVE \\
\hline \multirow[t]{4}{*}{ Trust } & B6 & .71 & .878 & 0.883 & 0.656 \\
\hline & B7 & .77 & & & \\
\hline & B8 & .89 & & & \\
\hline & B9 & .87 & & & \\
\hline \multirow[t]{3}{*}{ Commitment } & B13 & .81 & .880 & 0.883 & 0.716 \\
\hline & B14 & .88 & & & \\
\hline & B15 & .86 & & & \\
\hline \multirow[t]{4}{*}{ Communication } & B16 & .79 & .865 & 0.855 & 0.596 \\
\hline & B19 & .76 & & & \\
\hline & B20 & .72 & & & \\
\hline & B21 & .82 & & & \\
\hline \multirow[t]{2}{*}{ Conflict Handling } & B24 & .75 & .841 & 0.846 & 0.580 \\
\hline & B25 & .79 & & & \\
\hline
\end{tabular}




\begin{tabular}{|c|c|c|c|c|c|}
\hline \multirow{4}{*}{ Bonding } & B26 & .76 & \multirow{4}{*}{.891} & \multirow[b]{3}{*}{0.893} & \multirow[b]{3}{*}{$0.62 \epsilon$} \\
\hline & B28 & .73 & & & \\
\hline & B33 & .72 & & & \\
\hline & B35 & .80 & & & \\
\hline & B36 & .79 & & & \\
\hline \multirow{5}{*}{ Empathy } & B37 & .80 & & & \\
\hline & B38 & .84 & & & \\
\hline & B40 & .81 & \multirow[t]{3}{*}{.896} & \multirow[t]{3}{*}{0.902} & \multirow[t]{3}{*}{0.755} \\
\hline & B41 & .92 & & & \\
\hline & B42 & .87 & & & \\
\hline
\end{tabular}

Note: $\mathrm{CR}=$ Construct Reliability; AVE = Average Variance Extraction.

Table 4: Average Variance Extracted and Shared Variance Estimates

\begin{tabular}{lcccccc}
\hline Variable & Trust & Commitment & Communication & $\begin{array}{c}\text { Conflict } \\
\text { Handling }\end{array}$ & Bonding & Empathy \\
\hline Trust & $\mathbf{0 . 6 6}$ & 0.44 & 0.49 & 0.36 & 0.36 & 0.25 \\
Commitment & 0.66 & $\mathbf{0 . 7 2}$ & 0.64 & 0.59 & 0.49 & 0.36 \\
Communication & 0.70 & 0.80 & 0.66 & 0.64 & 0.49 & 0.49 \\
Conflict Handling & 0.60 & 0.77 & 0.80 & 0.58 & 0.34 & 0.56 \\
Bonding & 0.60 & 0.70 & 0.70 & 0.58 & $\mathbf{0 . 6 3}$ & 0.56 \\
Empathy & 0.50 & 0.60 & 0.70 & 0.76 & 0.75 & $\mathbf{0 . 7 6}$ \\
\hline
\end{tabular}

Note: Correlations are below the diagonal, squared correlations are above the diagonal, and AVE estimates are presented on the diagonal.

Finally, discriminant validity is the degree to which measures of different concepts are distinct. This study used two methods in assessing discriminant validity. First, the estimated correlation between factors should not be higher than 85 (Kline, 2005). As presented in Table 4, each correlation satisfies this requirement, supporting the condition of discriminant validity. Second method is comparing the value of the Average Variance Extracted (AVE) with the Squared Multiple Correlations (SMC) between constructs. A construct is considered has sufficient discriminant validity if the AVE exceeds the SMC among the constructs (Fornell and Larcker, 1981; Hair et al., 2006). This analysis indicates that the shared variances between factors are lower than the average variance extracted of the individual factors, hence confirming discriminant validity (see Table 4). In summary, the measurement model demonstrates adequate reliability, convergent validity, and discriminant validity. 


\section{Discussion and Conclusion}

Similar to suggestion from previous studies, all the dimensions are important and relevant in developing effective and efficient relationship marketing in the mobile service sector. However, it is important to note that every dimension has different degree of intensity in influencing relationship marketing.

Among all the dimensions, conflict handling concept is the best in explaining relationship marketing in this study. Although it is not used as much as other dimensions such as trust and commitment, this study provides evidence that conflict handling is an important factor that increasingly looked by customers, especially in the context of service. This finding is consistent with previous studies including Lingreen (2001), Ndubisi and Chan (2005), Ndubisi (2007) and Ndubisi et al. (2009) who recommended the important of conflict handling in the service-relationship marketing.

The second dimension that best explains relationship marketing in this study is bonding. As expected, this finding supports the suggestion given by Chattanon and Trimetsoontorn (2009), although it was initially found as significant to increase firm's performance. This finding therefore confirms that bonding is not only critical for relationship marketing in business to business (B2B) context, but in the customer context as well. This is because, the application of bonding to relationship marketing orientation involves developing and enhancing consumer loyalty, which results directly in feelings of affection, a sense of belonging to the relationship, and indirectly in a sense of belonging to the organization (Sin et al. , 2005).

Furthermore, communication and commitment are ranked third and fourth respectively among all the dimensions. This is similar with the previous studies that have consistently included both communication and commitment as important dimensions of relationship marketing, especially in customers' studies (e.g. Ndubisi and Chan, 2005; Ndubisi, 2007; Ndubisi et al., 2009; Kamaruzaman et al., 2009). The findings also confirm that two way communication is very significant for both companies and customers because it helps customers to interact with the service providers (Bennett and Barkensjo, 2005) by receiving emails, newsletters or mobile messages on any information regarding the services. On the other hand, this study obtains results consistent with the well-known theory of commitment and trust (Morgan and Hunt, 1994) which believed that successful relationship marketing requires relationship commitment. Although the original theory proposed that lack of relationship commitment influences rise to acquiescence and a propensity to leave, this study finds that commitment is a vital key of relationship marketing in order to persuade cross buying among customers. That is, the finding provides additional support about the significant influences of commitment on important outcomes that are discovered previously in different kinds of study settings such as decreased turnover (Porter et al., 1974), higher motivation (Farrell and Rusbult, 1981), increased organizational citizenship behaviors (Williams and Anderson, 1991), recruiting and training practices (Caldwell et al., 1990), job equity (Williams and Hazer, 1986), and organizational support (Eisenberger et al., 1990).

In explaining relationship marketing, empathy and trust are ranked fifth and sixth places respectively. As for empathy, the variance shows quite a high percentage $(70 \%)$, meaning that it is still significant in explaining the concept of relationship marketing. This finding therefore supports the study by Berger (2009), who believed that empathy is a missing element in relationship marketing. Excluding the element of empathy will lead to the failure of the firm in understanding customer's feelings and needs. 
With regards to the last dimension, this study finds that trust is no longer a main factor that contributes to the success of a customer-firm relationship. The reason to this finding is that, trust is only critical for customers in choosing a new service provider (Verhoef et al., 2002). However, as the relationship goes further, customers concentrate more towards the other issues such as conflict handling and communication, especially in purchasing similar categories of product offered by the same service provider. The underlying rationale is that when customers already have a certain level of trust on the quality of the services, their perceived risks with the service providers are reduced (Selnes, 1998). In fact, this is supported by Liu and Wu (2008) who believed that trust is less important in the case of similar cross buying as compared with dissimilar cross buying, since similar cross buying entails a relatively low level of perceived risk. Although it is not ranked as the first, this study confirms that trust is still relevant in developing a good relationship with customers as Bendapudi and Berry (1997) found that trust has an effect on relationship enhancement.

As for implications, this study contributes to both theoretical and methodological aspects. As there is little agreement among scholars as to which dimensions best capture the concept of relationship marketing, thus the significance and explanatory power of all the underlying dimensions (trust, commitment, communication, conflict handling, bonding and empathy) found in this study contributes to the theoretical development of relationship marketing, particularly in the service sector. Unlike other previous studies that employed three or four dimensions in explaining relationship marketing (e.g. Adamson et al., 2003; Ndubisi, 2007; Ndubisi et al., 2009), this study discovers many important dimensions most relevant to the service and customer context.

In terms of methodological, this study proves that the use of Structural Equation Model (SEM) is more effective due to its ability to estimate the multiple and interrelated dependence relationships simultaneously. Unlike other multivariate analyses which are typically piecemeal in nature, the SEM is able to test the model as a whole and shows the goodness-of-fit of the data to the hypothesized model. Without information about the model's goodness-of-fit, it is difficult to assess the adequacy of theory underlying the hypothesized model. In addition, the second order model used in this study is appropriate as the measurement instruments in this study are assessed using several related constructs, and each of them is measured by multiple items (Chen, Sousa and West, 2005). Unlike first-order model with correlated factors, second order factor model has the ability to provide more parsimonious and interpretable model (Chen et al., 2005).

From a managerial perspective, this study provides an idea to the practitioners that to be successful in a matured market like the Malaysian mobile service sector, a successful relationship marketing initiative should be implemented, through proactive and reactive conflict handling, beneficial bonding and effective two-way communication. In addition, the practitioners ought to build a sense of commitment both from the operator and customers' side. A necessary mechanism need also to be developed by practitioners in order to be more understanding of customers' problems, other than continuing to ensure that trust is compulsory in delivering their services effectively and efficiently. Indeed, each of the dimension needs to be managed carefully in order for the practitioners to obtain competitive advantage and even remain competitive. In addition, this study also gives an idea to the practitioners that implementation of relationship marketing initiative such as Customer Relationship Management (CRM) will benefit the firm. Using CRM, the practitioners can often manage every single contact with the customer through account management personnel, interactive voice response systems, call centers, online dial up applications, and web sites to build lasting profitable relationships. This kind of interaction 
helps the practitioners to gather information and insights about the customer needs and buying behavior and in turn develop services that enhanced value to the customers as well to the firm. Nevertheless, the practitioners have to remember that CRM benefits are only realized when corporate goals for Information and Communications Technology (ICT) are aligned with CRM applications as it is a critical component in CRM.

\section{Limitations and Future Research}

While this study makes a contribution to the body of knowledge, it has several limitations that need to be identified. First is about the sampling method. Although scientific procedures of mall intercept was employed where respondents were chosen every $5^{\text {th }}$ minutes, the generalization of this study would be less, compared if the purely random method is employed. As such, the generalization of this model is limited to mobile service sector and generalization to other future studies needs to be done with caution. Another limitation is related to the selection of the underlying dimensions of relationship marketing. Although this study finds that all the chosen dimensions are significant and explained relationship marketing well, this result is truly limited to the mobile service setting and customer based study. Due to this limitation, the application of these dimensions in the other research settings needs to be done with care.

While this study developed a model that provides the empirical influence of effective relationship marketing, it study also opens some additional avenues for future research. As the non-probability sampling method used in this study leads to the lack of generalization. Thus, the use of probability sampling such as stratified random sampling in a few different locations other than Klang Valley can improve the generalization of the findings. Furthermore, it would be more informative to test the model in different service sectors based on business to customer setting, especially to the sector that is less explored such as hospitality and transportation.

In conclusion, this study has demonstrated that the six key underpinnings are significantly important in measuring relationship marketing, at least in Malaysian mobile service sector. The instrument is empirically tested as a reliable and valid measurement and the model shows the parsimonious set of relationship marketing dimensions that can be used for further analysis such as to understand its influence on customer satisfaction, customer loyalty and cross buying. In the case of Malaysian mobile service sector, conflict handling explained relationship marketing the most, followed by bonding, communication, commitment, empathy and trust.

\section{References}

Adamson, I., Chan, K.M., and Handford, D. (2003). Relationship marketing: customer commitment and trust as a strategy for the smaller Hong Kong corporate banking sector, International Journal of Bank Marketing, 347-358. 
Alrubaiee, L. and Al-Nazeer, N. (2010). Investigate the Impact of Relationship Marketing Orientation on Customer Loyalty: The Customer's Perspective, International Journal of Marketing Studies,2 (1), 155174.

Andaleeb, S.S. (1992). The trust concept: research issues for channels of distribution. Research in Marketing, 11, 1-34.

Andersen, P.H. (2001). Relationship development and marketing communication: an integrative model. Journal of Business \& Industrial Marketing, 16 (3), 167-182.

Anderson, E. and Weitz, B. (1992). The use of pledges to build and sustain commitment in distribution channels, Journal of Marketing Research, 29 (1), 18-34.

Anderson, J. C., and Gerbing, D. W. (1988). Structural Equation Modeling in Practice: A Review and Recommended Two-Step Approach. Psychological Bulletin, 103(3), 411-423.

Anderson, J.C. and Narus, J.A. (1990), A model of distributor firm and manufacturing firm working partnership. Journal of Marketing, 54(1), 42-58.

Arantola, H. (2002). Consumer bonding-a conceptual exploration. Journal of Relationship Marketing, 1(2), 93-107.

Bagozzi, R. P. (1980). Causal Model in Marketing. New York: Wiley.

Bagozzi, R. P., and Yi, Y. (1988). On the evaluation of structural equation models. Journal of The Academy of Marketing Science, 16(1), 74-94.

Barlow J. and Maul, D. (2000). Emotional Value: Creating strong bonds with your customers. Berret Kohler Publishers, San Francisco.

Barnes, J. (2002). The impact of technology on customer relationships. Australian Marketing Journal, 9 (1), 21-31.

Bendapudi, N. and Berry, L. L. (1997). Customers' motivations for maintaining relationships with service providers. Journal of Retailing, 73(1), $15-37$.

Bennett, R. and Barkensjo, A. (2005). Relationship quality, relationship marketing, and client perceptions of the levels of service quality of charitable organizations. International journal of service industrial management, 16 (1), 81-106.

Berger, J.T. (2009). Empathy - The Missing Element in Relationship Marketing, The Wiglaf Journal, Retrieved from http://www.wiglafjournal.com/selling/2009/01/empathy-the-missing-element-inrelationship-marketing/

Berry, L L. (1983). Relationship Marketing. In Emerging Perspectives on Services Marketing. Eds. Leonard L. Berry, G. Lynn Shostack, and Gregory Upah. Chicago, IL: American Marketing Association, 25-28.

Berry, L.L. (1995). Relationship marketing of services - growing interest, emerging perspectives. Journal of the Academy of Marketing Science, 23(4), 236-45. 


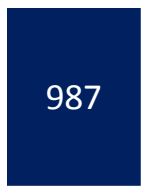

3rd INTERNATIONAL CONFERENCE ON BUSINESS AND ECONOMIC RESEARCH ( 3rd ICBER 2012 ) PROCEEDING

12 - 13 MARCH 2012. GOLDEN FLOWER HOTEL, BANDUNG, INDONESIA

ISBN: 978-967-5705-05-2. WEBSITE: www.internationalconference.com.my

Berry, L.L. and Parasuraman, A. (1991). Marketing service. New York: The Free Press.

Bitner, M.J. (1990). Evaluating service encounter: The effects of physical surroundings and employees responses. Journal of Marketing, 54 (April), 69-82.

Bitner, M.J., Booms, B.H. and Tetreault, M.S. (1994). The service encounter: Diagnosing favorable and unfavorable incidents. Journal of Marketing, 54 (January), 71-84.

Caldwell, D.F., Chatman, J.A., and O'Reilly, C.A. (1990). Building organizational commitment: A multi firm study. Journal of Occupational Psychology, 63, 245-61.

Callaghan, M., McPhail, J. and Yau, O.H.M. (1995). Dimensions of a relationship marketing orientation: an empirical exposition. Proceedings of the 7th Biannual World Marketing Congress, VII-II, Melbourne, Australia, July, 10-65.

Chattananon, A. and Trimetsoontorn, J. (2009). Relationship marketing: a Thai case, International Journal of Emerging Markets, 4(3), 252-274.

Chen, F.F., Sousa, K.H. and West, S.G. (2005): Teacher's Corner: Testing Measurement Invariance of Second-Order Factor Models, Structural Equation Modeling. A Multidisciplinary Journal, 12(3), 471-492.

Crosby, L.A., Evans, K.R. and Cowles, D. (1990). Relationship quality in services selling: an interpersonal influence perspective. Journal of Marketing, 54 (3), 68-81.

Cummings, T. (1984). Transorganizational development. Research in Organizational Behaviour, 6, 367422.

Day, G.S. (1995). Advantageous alliances. Journal of the Academy of Marketing Science, 23 (4), 297-300.

Department of Statistics Malaysia (2008). Vital Statistics Malaysia 2008 Department of Statistics Malaysia.

Duarte, M. and Davies, G. (2003). Testing the conflict-performance assumption in business-to-business relationships. Industrial Marketing Management, 32 (2), 91-99.

Dwyer, F.R., Schurr, P.H. and Oh, S. (1987). Developing buyer-seller relationships. Journal of Marketing, 51(2), 11-27.

Eisenberger, R., Peter, F. and Davis-LaMastro, V. (1990). Perceived Organizational Support and Employee Diligence, Commitment, and Innovation. Journal of Applied Psychology 75, 51-59.

Farrell, D. and Rusbult, C. (1981). Exchange Variables as Predictors of Job Satisfaction, Job Commitment, and Turnover: The Impact of Rewards, Costs, Alternatives, and Investment. Organizational Behavior and Human Performance 28, 78-95.

Fornell, C., and Larcker, D. F. (1981). Evaluating structural equation models with unobservable variables and measurement error. Journal of Marketing Research, 18(1), 39-50.

Grönroos, C. (1994). From marketing mix to relationship marketing: Towards a paradigm shift in marketing. Management Decision, 32 (2), 4-20. 

3rd INTERNATIONAL CONFERENCE ON BUSINESS AND ECONOMIC RESEARCH ( 3rd ICBER 2012 ) PROCEEDING

12 - 13 MARCH 2012. GOLDEN FLOWER HOTEL, BANDUNG, INDONESIA

ISBN: 978-967-5705-05-2. WEBSITE: www.internationalconference.com.my

Grönroos, C. (1999). Relationship marketing: Challenges for the organization. Journal of Business Research, 46 (3), 327-335.

Hair, J.F., Jr., Black, W.C., Babin, B.J., Anderson, R.E., and Tatham, R.L. (2006). Multivariate data analysis. $6^{\text {th }}$ ed. Upper Saddle River, NJ: Prentice Hall.

Holmes-Smith, P., Coote, L., and Cunningham, E. (2006). Structural Equation Modelling: From the Fundamentals to Advanced Topics. Melbourne: SREAMS.

Hsieh, Y., Chiu, H., and Chiang, M. (2005). Maintaining a committed online customer: A study across search-experience-credence products. Journal of Retailing, 81(1), 75-82.

Hsieh, Y.C. and Hiang, S.T. (2004). A study of the impacts of service quality on relationship quality in search-experince-credence service. Total Quality Management, 15(1), 43-58.

Hutt, M.D. and Speh, T.W. (1995), Business Marketing Management, 5th Edition, Dryden Press, Chicago, IL.

Jehn, K.A. (1995). A Multimethod Examination of the Benefits and Detriments of Intragroup Conflict. Administrative Science Quarterly, 40 (2), 256-282.

Jöreskog, K., and Sörbom, D. (1981). LISERL V: Analysis of Linear Structural Relationships by the Method of maximum Likelihood. Chicago: National Education Resources.

Kamaruzaman, J., Kamsol, M.K., Anuar, B., Norizah, K., and Nik Ramli, N.A.R. (2009). Retaining Customers through Relationship Marketing in an Islamic Financial Institution in Malaysia. International Journal of Marketing Studies, 1 (1), 66-71.

Kiesler, C.A. (1971). The Psychology of commitment, Academic Press, New York, NY.

Kline, R. B. (2005). Principles and Practice of Structural Equation Modelling (2 ${ }^{\text {nd }}$ ed.). New York: The Guilford Press.

Kline, R. B. (2011). Principles and Practice of Structural Equation Modelling ( $3^{\text {rd }}$ ed.). New York: The Guilford Press.

Kucukkancabas, S., Akyol, A. and Ataman, B.M. (2009). Examination of the effects of the relationship marketing orientation on the company performance. Research Note, 43, 441-450. DOI 10.1007/s11135007-9119-x.

Kumar, V., and Reinartz. W. (2002). The mismanagement of customer loyalty. Harvard Business Review, 80, 86-97.

Liang, C., and Wang, W. (2005). Integrative research into the financial services industry in Taiwan: relationship bonding tactics, relationship quality and behavioural loyalty. Journal of Financial Services Marketing, 10 (1), 65. 

3rd INTERNATIONAL CONFERENCE ON BUSINESS AND ECONOMIC RESEARCH ( 3rd ICBER 2012 ) PROCEEDING

12 - 13 MARCH 2012. GOLDEN FLOWER HOTEL, BANDUNG, INDONESIA

ISBN: 978-967-5705-05-2. WEBSITE: www.internationalconference.com.my

Lin, C.P. and Ding, C.G. (2005) Opening the Black Box: Assessing the Mediating Mechanism of Relationship Quality and the Moderating Effects of Prior Experience in ISP Service. International Journal of Service Industry Management, 16 (1), 55-80.

Lin, N.P., Weng, J. C. M. and Hsieh, Y. (2003). Relational bonds and customer's trust and commitment- a study on the moderating effects of web site usage. The Services Industries Journal, 23 (3), 103-127.

Lingreen, A. (2001). A framework for studying relationship marketing dyads. Qualitative Market Research: An International Journal, 4 (2), 75-87.

Liu, T.C. and Wu, L.W. (2008). Relationship quality and cross-buying in varying levels of category similarity and complexity, Journal of Total Quality Management, 19 (5), 493-511

Lovelock, C. (1983). Classifying services to gain strategic marketing insights. Journal of Marketing, 47, 920.

Mohr, J. and Nevin, J.R. (1996). Communication strategies in marketing channels: a theoretical perspective. Journal of Marketing, 54 (4), 36-52.

Mohr, J. and Spekman, R. (1994). Characteristics of partnership success: partnership attributes, communication behavior, and conflict resolution techniques. Strategic Management Journal, 15(2), 135152.

Moorman, C., Zaltman, G. and Deshpande', R. (1992). Relationships between providers and users of marketing research: the dynamics of trust within and between organizations. Journal of Marketing Research, 29 (3), 314-329.

Morgan, R.M. and Hunt, S.D. (1994). The commitment trust theory of relationship marketing. Journal of Marketing, 58 (3), 20-38.

Ndubisi, N.O, Malhotra, N.K. and Wah, C.K (2009). Relationship Marketing, Customer Satisfaction and Loyalty: A Theoretical and Empirical Analysis From an Asian Perspective, Journal of International Consumer Marketing, 21, $15-16$.

Ndubisi, N.O. (2003). Service quality: understanding customer perceptions and reaction, and its impact on business. International Journal of Business, 5 (2), 207-219.

Ndubisi, N.O. (2007). Relationship marketing and customer loyalty. Journal Marketing Intelligence \& Planning, 25 (1), 98-106.

Ndubisi, N.O. and Chan, C.K. (2005). Factorial and discriminant analyses of the underpinnings of relationship marketing and customer satisfaction. International Journal of Bank Marketing, 23 (7), 542557.

Nunnally, J. C. (1978). Psychometric Theory (2nd ed.). New York: McGraw-Hill.

Peltier, J.W., Westfall, J. (2000). Dissecting the HMO-benefits managers relationship: what to measure and why. Mark Health Serv, 20(2), 4-13. 
Porter, L. W., Richard, M. S., Richard, T. M. and Paul, V. B. (1974). Organizational Commitment, Job Satisfaction and Turnover among Psychiatric Technicians. Journal of Applied Psychology 59, 603-609.

Reichheld Frederick F. and Phil Schefter (2000). E-loyalty: Your secret weapon on the web. Harvard Business Review, 78 (4), 105-114.

Roberts K, Varki S, Brodie R. (2003). Measuring the quality of relationships in consumer services: an empirical study. European Journal of Marketing, 37(1/2), 169- 196.

Selnes, F. (1998). Antecedents and consequences of trust and satisfaction in buyer - seller relationships. European Journal of Marketing, 32 (3/4), $305-322$.

Sin, L.Y.M., Tse, A.C., Yau O., H., Lee, J.S., Chow, R. (2002). The effect of relationship marketing orientation on business performance in a service-oriented economy. J. Serv. Market. 16(7), 656-676.

Sin, L.Y.M., Tse, A.C.A., Yau, O.H.M., Lee, J.Y.S., Chow, R. and Lau, L.B.Y. (2005). Relationship marketing orientation: scale development and cross-cultural validation. Journal of Business Research, 58,185- 194.

Soureli, M., Lewis B.R. and Karantinou, K.M. (2008). Factors that affect consumers' cross-buying intention: A model for financial services, Journal of Financial Services Marketing, 13, 15-16.

Sullivan, J. and Peterson, R.B. (1982). Factors associated with trust in Japanese-American joint venture. Management International Review, 22 (2), 30-40.

Verhoef, P.C., Franses, P.H., and Hoekstra, J.C. (2002). The effect of relational constructs on customer referrals and number of services purchased from a multiservice provider: does age of relationship matter? Journal of Academy of Marketing Science, 30(3), 202-216.

Weirtz, B.A. and Jap, S.D. (1995). Relationship Marketing and Distribution Channels. Journal of the Academy of Marketing Sciences, 23 (4), 305-320.

Williams J.D., Han S.L., Qualls W.J. (1998). A conceptual model and study of crosscultural business relationships. Journal of Business Research, 42(2), $135-43$.

Williams, L. and Hazer, J. T. H. (1986). Antecedents and Consequences of Satisfaction and Commitment in Trust Models: A Reanalysis Using Latent Variable Structural Equations Methods, Journal of Applied Psychology, 71, 219-223.

Williams, L. J. and Anderson, E. A. (1991). Job Satisfaction and Organizational Commitment as Predictors of Organizational Citizenship Behaviors and In-Role Behaviors. Journal of Management 17(3), 601-607.

Wilson, D.T. (1995). An integrated model of buyer-seller relationships, Journal of the Academy of Marketing Science, 23 (4), 335-345.

Wong, A. and Sohal, A. (2002). Trust, Commitment and Relationship Quality. International Journal of Retailing \& Distribution Management, 30 (1), 34-50. 


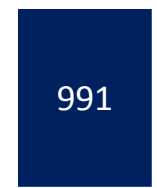

3rd INTERNATIONAL CONFERENCE ON BUSINESS AND ECONOMIC RESEARCH ( 3rd ICBER 2012 ) PROCEEDING

12 - 13 MARCH 2012. GOLDEN FLOWER HOTEL, BANDUNG, INDONESIA

ISBN: 978-967-5705-05-2. WEBSITE: www.internationalconference.com.my

Yau, O.H.M., Sin, L.Y.M., Lee, J.S.Y. and Tse, A.C.B. (1998). The development of a scale for measuring relationship marketing orientation, Working Paper RCCM99-01-0, Chinese Management Research Centre, City University of Hong Kong, Hong Kong.

Zeithaml, V.A., Berry, L.L and Parasuraman, A. (1993). The Nature and Determinant of Customer Expectation of Service. Academy of Marketing Science, 21(1), 1-12. 